Szent János Kórház és Észak-budai Egyesített Kórházai, II. Belgyógyászat-Diabetológia, az SE ÁOK Oktató- és Gyakorlóosztálya Budapest, ${ }^{1}$ Miskolci Egyetem Egészségügyi Kar, Elméleti Egészségtudományi Intézet, Miskolc²

\title{
A Diabetologia Hungarica negyedszázados története
}

\author{
Winkler Gábor dr. ${ }^{(1,2)}$
}

\begin{abstract}
Osszefoglalás
A szerzö - a folyóirat megindulásától a lap föszerkesztöje - áttekinti a Magyar Diabetes Társaság megjelenése negyedszázados évfordulóját ünneplö szakmai lapja, a Diabetologia Hungarica létrejöttének elözményeit és a folyóirat eddigi történetének fontosabb állomásait. Rámutat, hogy a lap folyamatosan bövülö rovataival, megújuló tartalmával messzemenöen teljesiti a Társaság missziós nyilatkozatában megfogalmazottakat, a cukorbetegséggel kapcsolatos elméleti és gyakorlati ismeretek naprakész követését, széleskörü terjesztését és ezek segitségével a hazai cukorbeteg-ellátás segitését, hatékonyságának erösitését. Ennek érdekében szorosan együttmüködik a Társaság elektronikus információforrásával, a Honlappal és a cukorbetegek számára készülö lapok szerkesztöségeivel is.
\end{abstract}

- Kulcsszavak: Diabetes-Információ, Diabetologia Hungarica, negyedszázados jubileum

\section{$25^{\text {th }}$ anniversary of Diabetologia Hungarica, official scientific journal of the Hungarian Diabetes Association}

Summary: The author-editor-in-chief since the appearance of the journal-overviews background and main historical events of Diabetologia Hungarica, the scientific journal of the Hungarian Diabetes Association celebrating $25^{\text {th }}$ anniversary of its foundation. It is pointed out, that the journal with its continuously expanding sections and renewable content broadly meets the goals stated in the mission statement of the Association, the up-to-date monitoring and widespread distribution of theoretical and practical knowledge regarding diabetes mellitus, and to support the diabetes care in Hungary. To realize these goals, a close collaboration was build up with the electronic information source, the homepage of the Association, as well as with editorial offices of lai diabetic journals.

- Keywords: Diabetes-Információ, Diabetologia Hungarica, $25^{\text {th }}$ anniversary

\section{DIABETOLOGIA HUNGARICA 25 (№3) 159-164. 2017. április}

\section{Rövidítések}

DESG: az Európai Diabetes Társaság Páciens Edukációs Munkacsoportja (Diabetes Education Study Group); DH: Diabetologia Hungarica; EASD: Európai Diabetes Társaság (European Association for the Study of Diabetes); ICDM: az IDF Diabetes Lapok Szerkesztőségeinek Nemzetközi Testülete (International Committee of Diabetes Magazine Makers); IDF: Nemzetközi Diabetes Szövetség (International Diabetes Federation); MDT: Magyar Diabetes Társaság

$\mathrm{J}$ óllehet, a Diabetologia Hungarica (DH) létrejötte formálisan 25 évre, 1993 elejére nyúlik vissza, gondolata már 10 évvel korábban, 1983-ban felmerült. Szakmai lap és általában újság indítása azonban az 1980-as években nem volt könnyen megvalósítható feladat. Egyrészről, mert a sajtó szoros állami (párt) felügyelet alatt állt, még a sokszorosításra alkalmas legegyszerűbb eszközöket - írógép, fénymásoló - is tételes nyilvántartással ellenőrizték. Részletes indoklás volt szükséges, ki, miért, milyen formában kíván újságot indítani, milyen nagyságú lesz és kikből verbuválódik a tervezett lap várható olvasóköre, a kéziratok milyen kontrollon mennek keresztül, 
a megjelenő írásoknak milyen visszhangja, társadalmi-politikai hatása várható. A felsoroltak alól a szakmai lapok sem jelentettek kivételt. Minden lapalapításban gondolkodó szervezet meggondolta tehát, kitegye-e magát a várható sorozatos vegzálásoknak.

Volt egy másik nehézség is. Ha a többszörös kontrollon átjutva végül zöld utat kapott, biztosítani kellett az újság folyamatos megjelentetését, az előállításához, terjesztéséhez szükséges anyagi hátteret. A hirdetések mai rendszere még nem létezett, s alapítványi források sem álltak rendelkezésre. A költségeket - jobb híján - a laptulajdonosnak, szakmai lapok esetében a szaktársaságnak kellett előteremtenie. Így azután, hiába tette időszerűvé önálló szakmai lap indítását az érintettek számának növekedése, a diabetesellátás szervezettségének erősödése, a szakellátóhelyek országos hálózatának kiépülése, a Magyar Diabetes

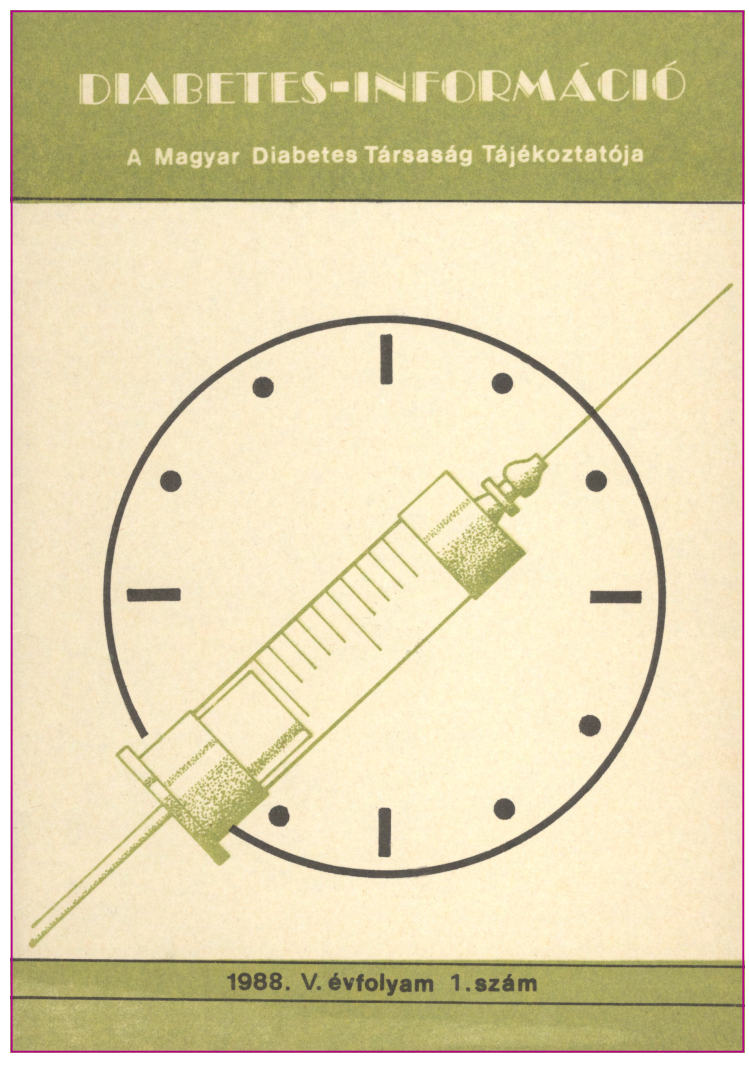

1. ábra. A Diabetologia Hungarica elödje, a DiabetesInformáció, az MDT periodikus tájékoztató kiadványa
Társaság (MDT) vezetősége ódzkodott az engedélyeztetési folyamat elindításától.

Hosszas egyeztetések után az elnök (Brooser Gábor professzor), a nemzetközi ügyekért felelős alelnök (Tamás Gyula) és a főtitkár (Békefi Dezső föorvos) hathatós támogatásának köszönhetően a vezetőség 1984-ben mégis hozzájárult egy hangsúlyozottan időszakos társasági tájékoztató kiadvány, a Diabetes-Információ elindításához. ${ }^{1}$ Addigra vagy az előírások enyhültek, vagy sikerült joghézagot találni, ma már alig kideríthető: a csak társasági tagokhoz eljuttatott tájékoztatókhoz nem kellett engedély, elegendő volt a bejelentése. Tartalmi ellenőrzését Békefi Dezső vállalta aki még ifjúságpolitikai felelősként már az előző vezetőségtől feladatul kapta a kiadás lehetőségének tisztázását (Békefi Dezsőtől származó személyes közlés) -, szerkesztésével ötletadóként engem bíztak meg, a szerkesztés munkájának segítésére pedig Asztalos Miklós és ifj. Petrányi Gyula kapott felkérést.

\section{A Diabetes-Információ}

Az A/5 méretű, 1984-től negyedévente, alkalmanként 16-20 oldalon, stencilezve, a második számtól kezdve egyszínnyomású, számonként eltérő színű borítóval, irkafüzéssel megjelenő kiadvány (1. ábra) gépelését a Kísérletes Orvostudományi Kutatóintézet egyik titkárnője vállalta, s ő intézte a sokszorosítást, előállítást is. A kiadvány alcímében „a Magyar Diabetes Társaság tájékoztatója” feliratot viselte, tartalmi vonatkozásban azonban sok tekintetben a későbbi DH előfutára volt. Beszámolt hazai és nemzetközi rendezvényekről, külföldi tanulmányutakon szerzett tapasztalatokról. Tájékoztatott a cukorbeteg-ellátással kapcsolatos rendelkezések módosulásairól, a vezetőségi ülések határozatairól, sőt, ha a terjedelem lehetővé tette - mint pl. az 1989. évi VI. évfolyam 3-4. számának 18-20. oldalán -, új metodikai eljárásokról is. A fent írtak miatt eléggé nem hangsúlyozható óvatosságot mindennél jobban tükrözi, hogy e szakmai leírás, a szigetsejt elleni antitest meghatározás összefoglalása után ott áll a szerkesztőség megjegyzése: „a »Diabetes-Információ« feladata Társaságunk életével kapcsolatos események ismertetése, a híradás. [...] szakmai 
anyagok publikálására csak ritkán vállalkozhatunk."

A tájékoztatót a Társaság minden bejegyzett tagja díjmentesen megkapta. A borítékolást, címzést, postázást családom bevonásával magam intéztem. A „szerkesztőség” 1989-ig - hivatalosan a Semmelweis Egyetem I. Belklinikáján működött, magam azonban már 1987-től újra régi munkahelyemen, a Szent János Kórház II. Belgyógyászati osztályán dolgoztam. Így azután - mivel Asztalos és Petrányi doktorok más elfoglaltságaik miatt már korábban abbahagyták a szerkesztéssel kapcsolatos tevékenységüket - 1990-től a kiadvány szerkesztőségi címe is a János kórházira változott.

E kiadvány újságnak jóindulattal sem nevezhető külleme, a mai DH-énál jóval szerényebb példányszáma ellenére komoly nemzetközi elismerésre tett szert. A volt „szocialista tábor” országai közül elsőként 1991-ben meghívást kapott a Nemzetközi Diabetes Szövetség (IDF) Diabetes Lapok Szerkesztőségeinek Nemzetközi Testülete (ICDM) szervezetébe (egy évvel később egy további hazai lap, a veszprémi kiadású, de országos terjesztésú pácienslap, a „Diabetes” és szerkesztője, Vándorfi Gyözö dr. is meghívást kapott). Rohamosan nőtt a kiadvány népszerűsége a tagság körében is, mindenki örült, hogy végre van a hazai diabetológiának „hivatalos” sajtófóruma is. Nem volt kéziratgond sem, a rövid terjedelmű cikkeket a Társaság vezető szakemberei írták (igaz, a megjelent írások vonatkozásában nem volt semmilyen formai követelmény meghatározva, a hangsúly a gyorsaságra és a tömör fogalmazásra helyeződött).

\section{A Diabetologia Hungarica megszületése}

A kedvező hazai fogadtatás és nemzetközi szakmai visszhang ellenére 1992 második felére a tájékoztató kiadvány „kifulladt”. Nem lehetett nem észrevenni, hogy már nem tölti be az elindításakor megfogalmazott célokat. Ennek több oka is volt. Egyfelől - a több évtizedes múltra visszatekintő Magyar Belorvosi Archivum mellett - új társasági lapok láttak napvilágot. Először, 1972-ben, a Kardiológiai Társaság indította el a Cardiologia Hungaricát, majd 1985-ben a Gasztroenterológiai Társaság is önálló folyóirat kiadásáról döntött. ${ }^{2} \mathrm{Az}$ 1990-ig negyedévenkénti rendszerességgel megje- lenő lap (Quaterly Bulletin of the Hungarian Society for Gastroenterology) angol neve ellenére többségében magyar nyelven jelentetett meg dolgozatokat. Az 1989-es rendszerváltást követően azután egyre több egészségügyi témájú, részben szakembereknek, részben nyilvános terjesztéssel, betegeknek szóló lap jelent meg, többségében figyelemfelhívó, színes borítóval, képes belső oldalakkal. E kiadványok között a korlátozott oldalszámú, stencilezett, fekete-fehér kiadvány már nem felelt meg az elvárásoknak.

Volt egy másik, legalább ennyire nyomós ok is. A Társaság taglétszáma rohamosan emelkedett. Míg 1988-ban 213 fizető tagot számlált, az 1990-es évek elejére meghaladta az 500-at, 1996-ban 635re, 2000-ben 1000 fölé nőtt. ${ }^{3}$ Ilyen példányszámban a stencilezés és a postázás már nem volt megoldható. A kiadvány 1992 szeptembere után nem jelent meg többé. Anyagi erőforrások e célra nem lévén úgy tủnt, a hazai diabetológia saját „sajtó” nélkül marad.

Fordulatot az 1993-as év hozott, amikor a Bayer Hungaria Kft. orvosigazgatója, dr. Riss Éva vá-

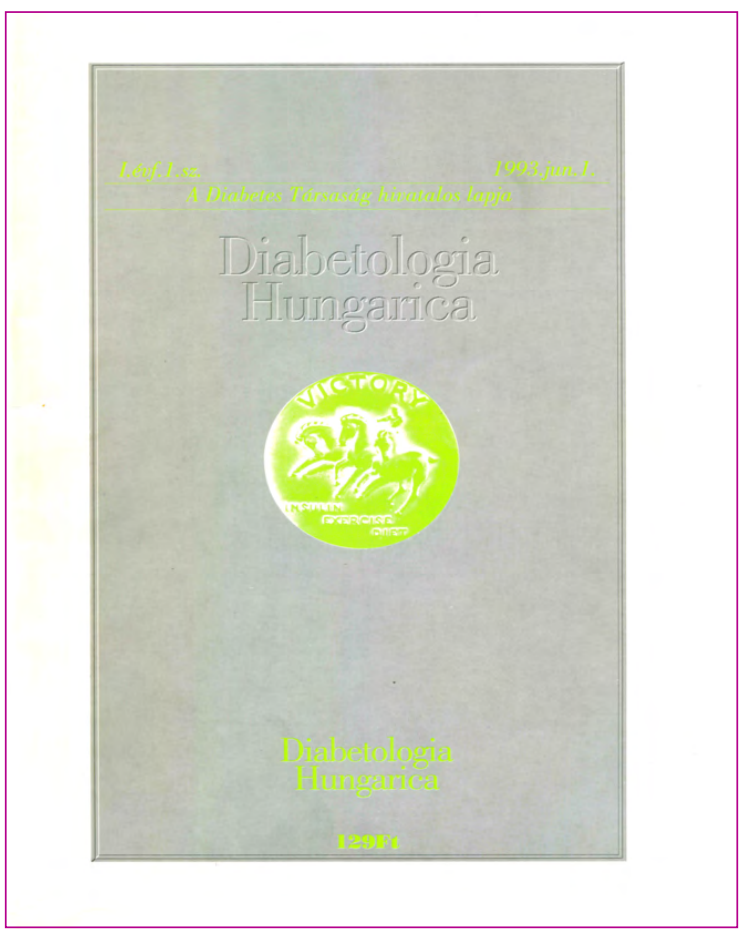

2. ábra. A Diabetologia Hungarica első lapszáma 
ratlan ajánlattal állt elő: alapítson a Társaság saját szakmai újságot. Ajánlatát megtetézte azzal, hogy magára vállalta a lapalapítással járó formaságok intézését és az első számok megjelentetésének költségeit. Javaslatát a Társaság elnöke, Halmos professzor és elnökségének a megbeszélésre megjelent tagjai - Pogátsa Gábor professzor, Jermendy György, Fövényi József és Winkler Gábor - örömmel fogadták. A Halmos professzor munkahelyén, az Országos Korányi Intézet X. Belosztályának főorvosi szobájában sebtében megtartott tanácskozás az „Információt” korábban szerkesztő Winkler Gábor személyében a főszerkesztőt is nyomban kinevezte. Munkája segítésére szerkesztőként Vándorfi Gyözö és Kautzky László kapott felkérést, a szerkesztőbizottságot pedig a Társaság elnöksége alkotta. ${ }^{1}$

Az első számban 36, a továbbiakban 48, A/4 méretű oldalon megjelenő, színes borítós folyóirat ( 2 . ábra) egy sor megoldandó kérdést is napvilágra hozott: mi az a reális megjelenési gyakoriság, ami

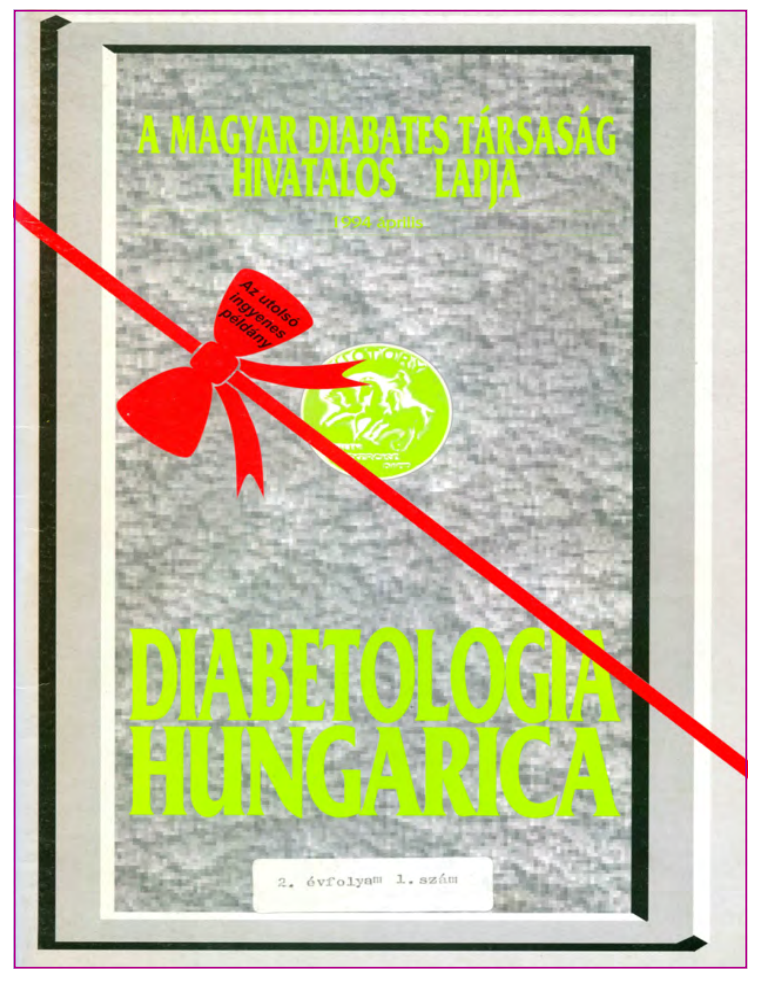

3. ábra. A Diabetologia Hungarica utolsó „ingyenes" példánya folyamatosan megtölthető tartalommal, elbírja-e a Társaság a kéthavonkénti-negyedévenkénti megjelenést, legyen-e előfizetési díj, avagy épüljön az be az éves tagdíjba? A szponzor e kérdések megoldásában is segítségünkre sietett. Vállalta, hogy mindaddig, amíg előfizetésekből és hirdetésekből a lap legalább önfenntartóvá nem válik, támogatja félvagy - elegendő információ esetén - negyedévenkénti megjelentetését, továbbá segít kiadó és hirdetők felkutatásában is.

Ahogy lapunk elődjét a tagság csak „Információ”-ként, az új folyóiratot is csakhamar „Hungarica”-ként kezdte emlegetni (és hívja nem hivatalosan ma is). Már az első szám után észlelni lehetett különböző gyógyszercégek hirdetéslehetőségek iránti érdeklődését, s aktivitásuk a mai napig is tart. Az utolsó, Bayer Hungaria által szponzorált, a tagsághoz díjmentesen kézbesített lapszám a negyedik, azaz az 1994. évi 1. szám volt (3. ábra). Ezt követően, 1995-től kezdve a lap a Tudomány Kiadó gondozásába került (borítóterve és belső grafikai szerkezete kialakítására a Serwise D stúdió kapott felkérést, napjainkban is itt készül a lap formai terve) (4. ábra). ${ }^{1}$

\section{A lap a számok és adatok tükrében}

Folyóiratunk példányonkénti ára indulásakor 129, megjelenése rendszeressé válásától kezdve 150 Ft volt. 1995-től kezdve eltűnt a lapszámok árának feltüntetése, az előfizetési díj az éves tagdíj része lett. A Társaság Kiadóval kötött szerződése szerint példányszáma a mindenkori fizető tagok és a közületi megrendelők (éves szinten 100-170) számával azonos, és mindig egy évre vonatkozóan kerül meghatározásra. Legnagyobb példányszáma 2200 volt. Az elektronikus - ezáltal pontosabban követhető - tagdijfizetési rendszer bevezetésének és a tagdíjfizetési fegyelem lanyhulásának köszönhetően csökkent, jelenleg 1300. A változó taglétszám esetenként gondot jelent kiemelt fontosságú lapszámok, pl. az MDT kezelési irányelveit közreadó számok esetében. A Kiadó ilyenkor jelentős számú többletpéldányt készíttet az utólagos igények lehető legteljesebb kielégítése céljából. (Eddig mindössze egy ízben fordult elő, hogy valamely lapszámból utólag pótnyomásra kellett sort keríteni.) 


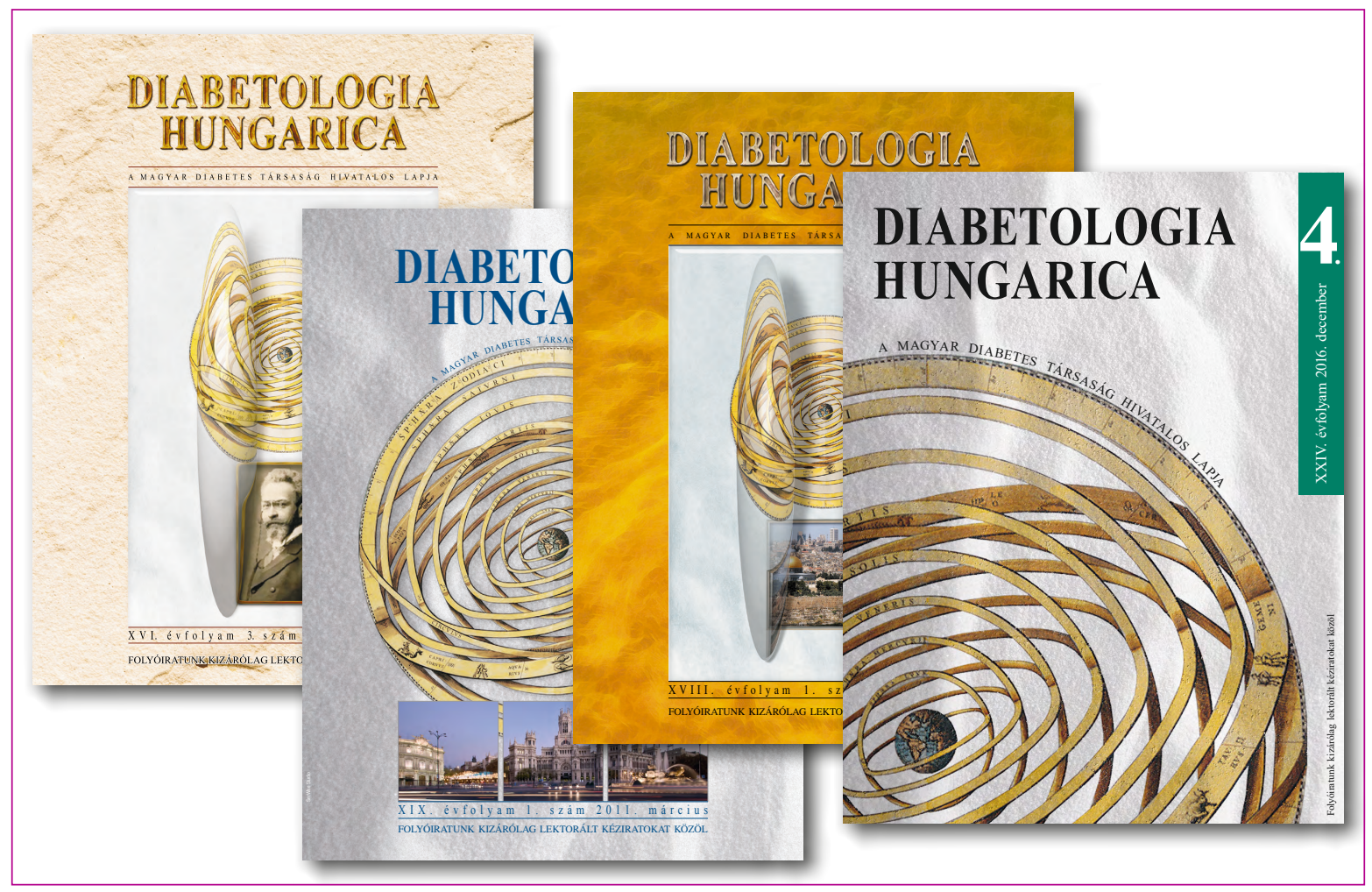

\section{4. ábra. Egy csokor a „DH" színes borítóiból}

A folyóirat rovatai között kezdettől fogva szerepeltek eredeti és összefoglaló közlemények, esetismertetések, valamint 2010-ig külföldi lapokban megjelent közlemények alapján íródott referátumok. Hosszú időn keresztül közreadtunk kongresszusi beszámolókat is hazai, illetve nemzetközi szakmai és szakmapolitikai rendezvényekről, számuk emelkedésével azonban előbb csak a nemzetközi konferenciákról szóló beszámolókat tartottuk meg, majd felismervén, hogy egyre több kolléga jut el a legrangosabb kongresszusokra is, beszüntettük e rovatot. Jermendy professzor javaslatára 1999-ben indult a nagy nemzetközi vizsgálatok eredményeit bemutató Diabetológiai Témájú Közlemények Tára, a Diabeto-Téka, a 2000-es évek elején a Fórum rovat, amelyben szélesebb körű megbeszélésre igényt tartó, eldöntendő kérdéseket megfogalmazó munkákat jelentettünk meg. Hidvégi föorvos gondozásában és fordításában jelentek meg 2004-2011 között Diabetes-Edukáció rovatunkban az Európai Diabetes Társa- ság (EASD) Diabetes Edukációs Munkacsoportja (DESG) oktatólevelei, ő gondozza a szakdolgozói rovatot is. A „Levél a főszerkesztőhöz” és társaságunk régi tagjai visszaemlékezéseit közreadó „Diabetologia anno...” rovatunk teszi teljessé a tartalmat.

A lap szerkesztőbizottsága a vezetőség 3-5 évenkénti megújulásával párhuzamosan időről időre változott (a Társaság Alapszabálya több ízben módosult, ez magyarázza az alkalmanként megbízást kapó vezetőség működésének eltérő időtartamát). Kautzky föorvos időközben olvasószerkesztővé lépett elő, Vándorfi föorvos helyét pedig Hidvégi föorvos foglalta el. A DH a 2. évtől, 1994től kezdve évi 4 rendes számmal jelent meg. A 3. évfolyamban került sor először különszám (supplementum) közreadására, ezt követően az MDTkongresszusokra bejelentett és elfogadott előadások - 1999-től kezdve két, magyar és angol nyelvü - kivonatai, valamint a mindenkori módszertani irányelvek különszám formájában jelentek meg. 
Supplementumként adtunk közre szponzorált kiadványokat is, pl. egy-egy jelentősebb gyógyszerkészítmény hazai forgalmazásba kerülésekor.

A 2002-ben Budapesten tartott EASDkongresszus alkalmából a lap angol nyelvű különszámot jelentetett meg, amely a hazai diabetológia reprezentánsainak áttekintő, egyben a hazai diabetológiai ellátást is bemutató munkáit adta közre. E kiadványt minden résztvevő kongresszusi táskájába eljuttattuk.

Nevezetes különszám a 19. évfolyam 3. supplementuma is 2011-ből, amely a Nemzeti Diabetes Program teljes, megújított szövegét tartalmazza. Ismeretes módon ez a Nemzeti Diabetes Program harmadik, teljesen átdolgozott változata, de az első, amely teljes terjedelmében a tagság elé került.

\section{Tervek a lap megújulására}

Az évek során a DH elismert helyet vívott ki a hazai szakmai lapok sorában. Folyamatossá vált olvasottsága - más, rokon szakmai társaságok tagsága körében is - és megtartott maradt a hirdetők érdeklődése is. Mind gyakrabban kellett ugyanakkor szembenéznünk azzal - a hazai lapok többségét sújtó - gonddal, hogy a kéziratküldési kedv igen változó, s ennek oka a nemzetközi ismertség és az ezzel szorosan összefüggő impakt faktor hiánya. Az MDT 2016-ban megválasztott vezetősége és a lap megújult szerkesztőbizottsága ezért kiemelt feladatának tekintette, hogy - több hazai rangos folyóirat, pl. az Ideggyógyászati Szemle / Clinical Neuroscience és az Orvosi Hetilap példáját szem előtt tartva - e téren is előrelépjen.

Első lépésként megalakult a lap nemzetközi szakmai tanácsadó testülete. Munkájába olyan elismert szakemberek kaptak felkérést, akik a diabetológia számon tartott képviselői, hosszabb ideje kapcsolatot tartanak az MDT-vel és értenek/beszélnek magyarul.

Második lépésként ez évtől kezdve megszűnik a lapszámok és supplementumok eddigi rendszere. A szponzorált kiadványok és a kongresszusi előadás-kivonatokat tartalmazó számok kivételével minden lapszámunk számozottá válik, s bennük minden közlemény elfogadásától kezdve önálló DOI számot kap. Így lehetővé válik, hogy a szer- zők már a nyomtatott változat megjelenése előtt hivatkozhassanak munkáikra.

A további teendők meghatározásához segítséget kértünk Vasas Lívia szaktanácsadó asszonytól, a Semmelweis Egyetem ÁOK kari könyvtára volt igazgatójától, számos folyóirat tanácsadójától, aki felkérésünket elfogadta és segíti munkánkat.

Az előzőekben összefoglaltak ismeretében talán nem túlzás azt állítani, hogy a DH sikeres huszonöt évet tudhat maga mögött. S bár Társaságunk közelgő kongresszusán ez alkalomból tanácsadó testületünk meghívott tagjainak részvételével ünnepi ülést is tervezünk, nem az ünneplésé, hanem a folyamatos munkáé lesz a szerep az elkövetkező időben is. Bízom a lap jövőjében, s abban, hogy erőfeszítéseink további céljaink megvalósításában is sikerrel járnak majd.

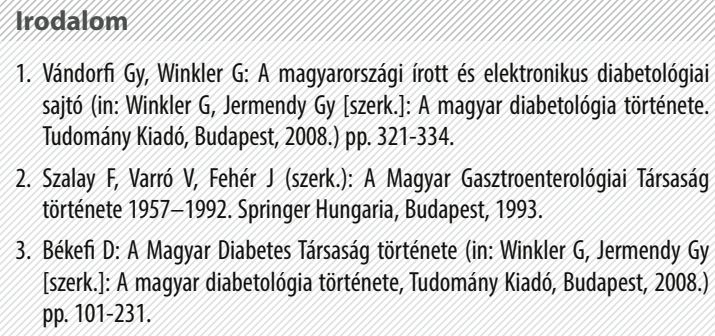

1. Vándorfi Gy, Winkler G: A magyarországi irott és elektronikus diabetológiai sajtó (in: Winkler G, Jermendy Gy [szerk.]: A magyar diabetológia története. Tudomány Kiadó, Budapest, 2008.) pp. 321-334.

2. Szalay F, Varró V, Fehér J (szerk.): A Magyar Gasztroenterológiai Társaság története 1957-1992. Springer Hungaria, Budapest, 1993.

3. Békefi D: A Magyar Diabetes Társaság története (in: Winkler G, Jermendy Gy [szerk.]: A magyar diabetológia története, Tudomány Kiadó, Budapest, 2008.) pp. 101-231.

A szerzö levelezési címe:

\section{Dr. Winkler Gábor}

Szent János Kórház, II. Belgyógyászat-Diabetológia, 1125 Budapest, Diós árok 1-3.

E-mail: gabor.winkler@janoskorhaz.hu 